\title{
Physicochemical and microbiological characterization of effluents from the "Centre Hospitalier Universitaire de la Mère et de l'Enfant Lagune (CHU-MEL)" discharged in the Cotonou lagoon in Benin
}

\section{Elias Alexandre Sètondji ADANLOKONON ${ }^{1,2 *}$, Wilfried Gbèdodé KANHOUNNON ${ }^{3}$, Boni Christophe $\mathrm{CHABI}^{4}$, Dogbè Clément ADJAHOUINOU ${ }^{2}$, Luc KOUMOLOU ${ }^{1}$, Brice BONOU ${ }^{1}$, Emile Didier FIOGBE ${ }^{2}$ and Patrick Aléodjrodo EDORH ${ }^{1}$}

\author{
${ }^{1}$ LaRBiTE : Laboratoire de Recherche en Biochimie et de Toxicologie de l'Environnement Université \\ d'Abomey-Calavi, 03 BP 0994 Jéricho-Cotonou, Bénin. \\ ${ }^{2}$ LRZH : Laboratoire de Recherches sur les Zones Humides Université d'Abomey-Calavi, 01 B.P. 526 Cotonou, \\ Bénin. \\ ${ }^{3}$ LACTHESMO : Laboratoire de Chimie Théorique et de Spectroscopie Moléculaire Université d'Abomey- \\ Calavi, 03 BP 3409 Cotonou, Bénin. \\ ${ }^{4}$ Fundamental and Biological Sciences Department of University of Parakou. \\ *Corresponding author; E-mail: elialexandresetondji@yahoo.fr; Tel: 0022966261175 / 0022995201431
}

\begin{abstract}
This study is carried out to characterize the CHU-MEL effluents discharged into the Cotonou lagoon to assess the potential hazards of these releases for this ecosystem. To achieve this goal, the effluents collected at the end of the spillways have been analyzed. The results obtained from the physicochemical and microbiological analysis made it possible to assess the quality of the effluents. The $\mathrm{pH}$, temperature and conductivity measured in-situ are, on average, $6.65,30.3{ }^{\circ} \mathrm{C}$ and $763 \mu \mathrm{S} / \mathrm{Cm}$. The average contents of dissolved oxygen, nitrite, nitrate, ammonium and Nitrogen Total Kjedhal (NTK) are respectively $1.92 \mathrm{mg} / \mathrm{L}, 0.06 \mathrm{mg} / \mathrm{L}, 7.75 \mathrm{mg} / \mathrm{L}, 18.45 \mathrm{mg} / \mathrm{L}$ and $28.78 \mathrm{mg} / \mathrm{L}$. The Biochemical Oxygen Demand (BOD5) ranges from $38 \mathrm{mg} / \mathrm{L}$ to $53 \mathrm{mg} / \mathrm{L}$, the Chemical Oxygen Demand (COD) from $97 \mathrm{mg} / \mathrm{L}$ to $274 \mathrm{mg} / \mathrm{L}$, suspended solids (SS) belonging between $47 \mathrm{mg} / \mathrm{L}-398$ $\mathrm{mg} / \mathrm{L}$ and total phosphorus going from $0.37 \mathrm{mg} / \mathrm{L}$ to $13.02 \mathrm{mg} / \mathrm{L}$. The microbiological parameters (total coliforms, faecal coliforms, E. coli, fecal streptococci and anaerobic sulphite reducers' spores) are generally out of the standard values. These effluents present therefor risks for the fauna and the flora of the Cotonou's lagoon and it is well indicated to assess them through ecotoxicity tests.
\end{abstract}

(C) 2018 International Formulae Group. All rights reserved.

Keywords: Hospital effluents, physicochemical parameters, microbiological parameters, pollution.

\section{INTRODUCTION}

The question of the presence of pollutants and the problems they generate in aquatic ecosystems is a major international concern because of environmental, health and economic issues. Among the different types of pollutants, those of hospital effluents must be paid a close attention. Effluents, generated by hospital activities, present a danger to human and his environment; due to their nature and the 
importance of the specific substances they contain (drug residues, chemical reagents, antiseptics, detergents, etc.) (Boillot, 2008). Their management is becoming more and more important in public health concerns. This upsurge interest relates, on the one hand, to the importance of the risk linked to the production of waste raised from healthcare activities and, on the other hand, to the nuisances to both health and environment which can be caused by the treating technique of waste (DHSA, 2004). Indeed, hospitals generate a large quantity of liquid effluents containing many micropollutants discharged into urban networks without prior treatment, as well as conventional domestic wastewater (Boillot, 2008; Hisseien et al., 2015) that is poured in the natural environment without a clear idea of their effects on it (Emmanuel, 2004) mainly in developing countries.

Effluents, once released in the environment with their pathogen agents and pharmaceutical products, the local fauna and flora are permanently under risks. Indeed, the specificity of hospital effluents is related to its high degree of toxicity. Even at a very low concentration, substances contained in hospital effluents can affect animal lives: estrogens for example can cause fishes to be hermaphrodite (Qadouri et al., 2016).

Several studies on the characterization of hospital effluents have been conducted throughout the world (Leprat et al., 2002; Emmanuel, 2004; Hartemann et al., 2005; Zounkovà et al., 2006; Sadek et al., 2012; Bouzid et al., 2013; Touré et al., 2016). Some of these studies also highlight the intrinsic ecotoxicity of these hospital effluents,

5 to 15 times higher than that of urban effluents. This ecotoxicity is related to substances contained in these effluents, such as the case of bleach used in laboratories in order to eliminate pathogen germs (Philippot et al., 2016).

According to WHO (2016), Heath centers are not equipped and have not access to sanitation installations. When even in some extremely rare cases they have water connections, there are hardly reliable and not adapted to the needs of patients, sanitary personal and to visitors too. The fact is more severe in developing countries.

In Benin, very few characterization studies of hospital effluents have been realized. From the few that have been carried out, it comes out that the quality of the effluents is unsatisfactory when compared with the existed standard. These effluents, through the infiltration process, contaminate shallow groundwater (Makoutodé et al., 2000; Aissi et al., 2010). In Decree No 2006-087 of 08 March 2006 on the national policy of hospital hygiene of the Ministry of Health of Benin, it is stated that "most of health center do not dispose of appropriate structures for the liquid waste collection and treatment (activated sludge or bacterial bed treatment station). In some cases, liquid waste is discharged into the washing basin and drained to the septic tank. In other cases, they are discharged directly into the public sewer when it exists, and sometimes, they are even discharged into the environment. It is the case of CHU-MEL which effluents are oriented in Cotonou's lagoon. This practice contributes to environmental pollution and exposes the population to infections caused by multi-resistant germs ".

On the basis of these facts, it was considered useful to characterize the effluent discharged by CHU-MEL in the Cotonou lagoon in order to evaluate the potential dangers of these discharges on this ecosystem.

\section{MATERIALS AND METHODS Study area}

The area study is subjected to subequatorial climate characterized by four seasons including a long dry season (LDS) from December to March, a long rainy season (LRS) from April to July, a short dry season (SDS) from August to September and a short rainy season (SRS) from October to November (Adam and Boko, 1993). The current study has been carried out on the effluents of the CHUMEL. The CHU-MEL is specialized in the care of mother and child. It is located in the town and close to the edge of the Cotonou lagoon as showed on figure 1. Liquid effluents resulting from the various activities of the hospital 
undergo a sort of treatment and are drained into the lagoon by underground pipe.

\section{Water sampling}

All sampling was carried out in the morning around 9 o'clock at the end of the pipes used as effluent dumps in the Cotonou lagoon, with the highest discharge rates obtained between $7 \mathrm{~h}$ et $10 \mathrm{~h}$. All the samples were kept in cool box $\left(4^{\circ} \mathrm{C}\right)$ to the laboratory.

For the physicochemical and microbiological analysis, two sampling campaigns were carried out in 2015, one in October (E1) in rain season and the Second one four weeks later in November (E2) corresponding to the beginning of the dry season. Samples for physicochemical analysis were taken from 1.5 L plastic bottles rinsed three times with the effluent to be sampled. The bottles were fully filled. Those for microbiological analysis were taken from presterilized $250 \mathrm{~mL}$ glass bottles. They were filled to $3 / 4$ of their volume. All samplings were kept in icebox filled of ice to the laboratory for analysis purpose.

\section{Effluents characterization}

In order to determine the quality status of the CHU-MEL effluents, we focused on certain parameters allowing the assessment of water quality. These parameters are $\mathrm{pH}$, conductivity, salinity, dissolved oxygen concentration, nitrogenous compounds $\left(\mathrm{NH}_{4}^{+}, \mathrm{NO}_{3}^{-}, \mathrm{NO}_{2}^{-}, \mathrm{NTK}\right)$, total phosphorus, free chlorine, suspended solids (SS), BOD COD and two heavy metals (lead and chromium). Table 1 lists the parameters measured on the effluent as well as the methods used. The microbiological characterization in this study was to search for total flora, total coliforms, presumptive Escherichia coli, faecal Streptococci, anaerobic sulphite reducers' spores spores according to the methods summarized in Table 2.

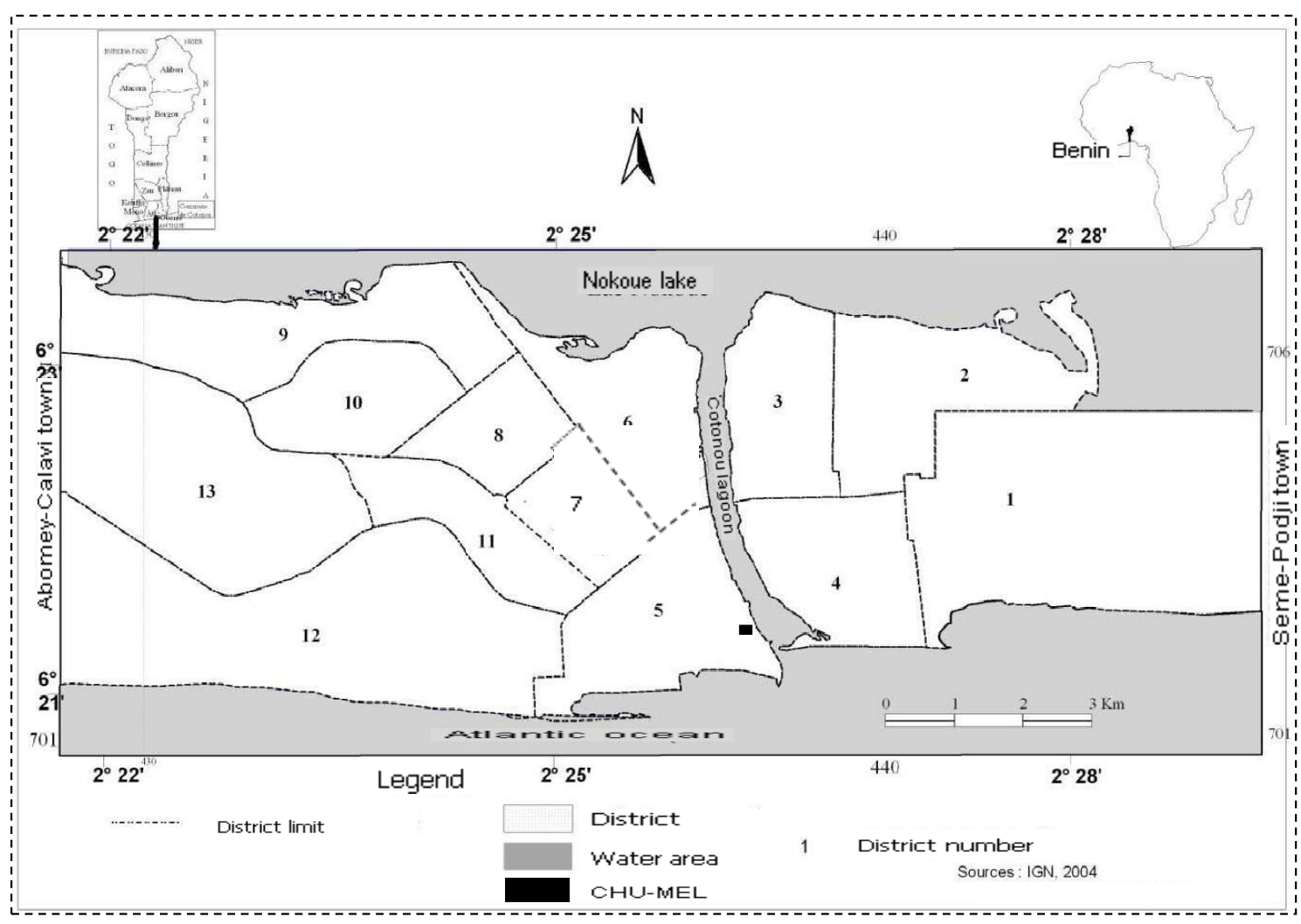

Figure 1: Cotonou town map presenting the position of its Cotonou lagoon. 
Table 1: Physico-chemical parameters and methods useds.

\begin{tabular}{|c|c|c|}
\hline Monitored parameters & Materials and used methods & References \\
\hline $\begin{array}{l}\mathrm{pH}, \text { Temperature, } \\
\text { Conductivity, Salinity }\end{array}$ & $\begin{array}{l}\text { Direct measurement by multi-parameter pH / } \\
\text { Conductmeter WTW 340i }\end{array}$ & $\begin{array}{l}\text { NF T } 90-008) \\
\text { NF T } 90-029\end{array}$ \\
\hline Disolved Oxygen & Potentiometry. Electrochemical method & NF EN 25814 \\
\hline Suspension Solids & Colorimeter Method HACH DR 890 & \\
\hline Nitrate & Colorimeter. Cadmium reduction method & \multirow{4}{*}{ NFT EN 26777} \\
\hline Nitrite & Colorimeter. Diazotization method & \\
\hline Ammonium, & The Nessler Method & \\
\hline Nitrogen Total Kjedhal & The Nessler Method & \\
\hline $\begin{array}{l}\text { Biochemical Oxygen } \\
\text { Demand (BOD5) }\end{array}$ & $\begin{array}{l}\text { Oxytop Respirometric method in a thermostatic } \\
\text { chamber }\end{array}$ & NF EN 1899-2 \\
\hline $\begin{array}{l}\text { Chemical Oxygen Demand } \\
\text { (COD) }\end{array}$ & Colorimeter. Potassium dichromate method & NF T90-101 \\
\hline Total Phosphorus & Acid ascorbic Method & NF EN ISO 15681-2 \\
\hline Hexavalent Chromium & Chromaver 3 method (HACH 8023) & NF EN ISO 18412 \\
\hline Lead $(\mathrm{Pb})$ & Dithizone method (HACH 8033) & NF EN ISO 15586 \\
\hline Free chlorine & Colorimeter. DPD1 method & NF EN ISO 7393-2 \\
\hline
\end{tabular}

Table 2: Microbiological parameters measured and methods used.

\begin{tabular}{|c|c|c|c|c|c|}
\hline Microorganisms & Culture area & Seeding mode & $\begin{array}{l}\text { Incubation } \\
\text { duration }\end{array}$ & $\begin{array}{c}\text { Particular } \\
\text { observations }\end{array}$ & References \\
\hline Total Coliforms & MacConkey & $\begin{array}{l}\text { Seeding in the } \\
\text { mass }\end{array}$ & $24 \mathrm{~h}$ à $37^{\circ} \mathrm{C}$ & Red colony & $\begin{array}{l}\text { NF EN ISO 9308-3 } \\
\text { (1999) }\end{array}$ \\
\hline Faecal Coliforms & $\begin{array}{l}\text { sorbitol BCIG } \\
\text { E.coli/coliform }\end{array}$ & Seeding in the & 24 h à $37^{\circ} \mathrm{C}$ & Red colony & $\begin{array}{l}\text { NF EN ISO 9308-3 } \\
\text { (1999) }\end{array}$ \\
\hline Escherichia coli & secrogigy Agar & $\begin{array}{l}\text { mass } \\
\text { Seeding in the } \\
\text { mass }\end{array}$ & $24 \mathrm{~h}$ à $37^{\circ} \mathrm{C}$ & Blue colony & $\begin{array}{l}\text { NF EN ISO 9308-3 } \\
\text { (1999) }\end{array}$ \\
\hline $\begin{array}{l}\text { Faecal } \\
\text { Streptococci }\end{array}$ & $\begin{array}{l}\text { Slanetz and } \\
\text { Bartley Agar } \\
\text { of } \\
\text { (Oxoid, CM } \\
\text { 0377) }\end{array}$ & $\begin{array}{l}\text { Seeding in the } \\
\text { mass }\end{array}$ & 48 h à $37^{\circ} \mathrm{C}$ & Red colony & NF ISO 7899-2 \\
\hline $\begin{array}{l}\text { anaerobic sulphite } \\
\text { reducers' spores }\end{array}$ & $\begin{array}{l}\text { Meat-liver } \\
\text { Agar (Oxoid, } \\
\text { CM 0918) }\end{array}$ & $\begin{array}{l}\text { Seeding in the } \\
\text { mass }\end{array}$ & $\begin{array}{l}24 \text { à } 48 \text { h à } \\
\quad 37^{\circ} \mathrm{C}\end{array}$ & $\begin{array}{l}\text { Colony } \\
\text { rounded by } \\
\text { black halo }\end{array}$ & $\begin{array}{l}\text { NF EN 26461-1- } \\
\text { ISO } 6461-1\end{array}$ \\
\hline
\end{tabular}




\section{RESULTS}

\section{Physicochemical characterization}

The physicochemical characteristics of CHU-MEL effluents compared to certain standards are summarized in Table 3. These results are compared to the standard of WHO and to those adopted in Benin. They showed that the $\mathrm{pH}$, the temperature, the conductivity and concentrations of nitrites, nitrates, lead and chromium are in line with standard. However ammonium, total nitrogen, total phosphorus, suspension substances concentrations, BOD5 and COD are higher than the standard (Table 3 ).

From the first to the second sampling, the values of certain parameters underwent remarkable variation. In fact, concentrations of NTK, total phosphorus, $\mathrm{SS}, \mathrm{BOD}_{5}$ and $\mathrm{COD}$ have significantly dropped. On the other hand, those of dissolved oxygen and ammonium nearly tripled (Table 3).
According to studies realized by Hartemann et al. (2005) and Mohee (2005), these fluctuations may depend on the origin and the effluent sampling moment. Indeed, they have proved in their work that the pollutant constituents vary according to the specificity of the hospitals, the place and even according to the moment of effluents sampling in the day.

\section{Microbiological characterization}

The identified bacterial species and counted in the CHU-MEL effluents are both total and faecal coliforms, faecal streptococci, clostridium spores and other germs. The obtained results are gathered in table 4 . The values obtained for these different groups of microorganisms are significantly higher than the WHO standard (2012) of $10^{3} \mathrm{UFC} / 100 \mathrm{~mL}$ for direct release into the environment.

Table 3: CHU-MEL effluents physicochemical parameters values along with sampling moments.

\begin{tabular}{|c|c|c|c|c|c|}
\hline \multirow{2}{*}{ Parameters } & \multirow{2}{*}{ Unities } & \multicolumn{2}{|c|}{ Sa apling } & \multirow{2}{*}{$\begin{array}{l}\text { mean } \\
\text { values }\end{array}$} & \multirow{2}{*}{$\begin{array}{l}\text { Acceptable } \\
\text { Standard } \\
\text { (WHO Benin ) }\end{array}$} \\
\hline & & $\mathbf{E}_{1}$ & $\mathbf{E}_{2}$ & & \\
\hline $\mathrm{pH}$ & & 6,76 & 6,54 & 6,65 & $6-9$ \\
\hline Temperature & ${ }^{\circ} \mathrm{C}$ & 29,6 & 31,00 & 30,3 & $<30$ \\
\hline Conductivity & $\mu \mathrm{S} / \mathrm{cm}$ & 738 & 788 & 763 & $<2000$ \\
\hline Dissolved Oxygen & $\mathrm{mg} / \mathrm{L}$ & 0,84 & 3,08 & 1,96 & $\geq 5$ \\
\hline Nitrite $\left(\mathrm{N}-\mathrm{NO}_{2}{ }^{-}\right)$ & $\mathrm{mg} / \mathrm{L}$ & 0,043 & 0,077 & 0,06 & $<3$ \\
\hline Nitrate $\left(\mathrm{N}-\mathrm{NO}_{3}{ }^{-}\right)$ & $\mathrm{mg} / \mathrm{L}$ & 8,0 & 7,5 & 7,75 & $<50$ \\
\hline Ammonium $\left(\mathrm{N}-\mathrm{NH}_{4}{ }^{+}\right)$ & $\mathrm{mg} / \mathrm{L}$ & 14,4 & 32,5 & 23,45 & $<0,2$ \\
\hline $\begin{array}{l}\text { Nitrogen Total Kjeldhal } \\
\text { (NTK) }\end{array}$ & $\mathrm{mg} / \mathrm{L}$ & 57 & 0,56 & 28,78 & $<15^{*}$ \\
\hline Total Phosphorus & $\mathrm{mg} / \mathrm{L}$ & 13,02 & 0,37 & 6,695 & $<10$ \\
\hline SS & $\mathrm{mg} / \mathrm{L}$ & 398 & 47 & 222,5 & $<20$ \\
\hline $\mathrm{BOD}_{5}$ & $\mathrm{mg} / \mathrm{L}$ of $\mathrm{O}_{2}$ & 53 & 38 & 45,5 & $<25^{*}$ \\
\hline COD & $\mathrm{mg} / \mathrm{L}$ of $\mathrm{O}_{2}$ & 274 & 97 & 185,5 & $<90$ \\
\hline Lead & $\mu \mathrm{g} / \mathrm{L}$ & 0,112 & 0,187 & 0,159 & $<1 *$ \\
\hline Chromium $\left(\mathrm{Cr}^{6+}\right)$ & $\mathrm{mg} / \mathrm{L}$ & 0,032 & 0,092 & 0,06 & $<0,1^{*}$ \\
\hline Free Chlorine $\left(\mathrm{Cl}_{2}^{-}\right)$ & $\mathrm{mg} / \mathrm{L}$ & 0,32 & 0,34 & 0,33 & \\
\hline
\end{tabular}

* Benin standard 
Table 4: Microbiological characteristics.

\begin{tabular}{llllll}
\hline & \multicolumn{2}{l}{ Sampling } & & \multicolumn{2}{c}{$\begin{array}{l}\text { Acceptable } \\
\text { Standard } \\
\text { (WHO) }\end{array}$} \\
\cline { 2 - 3 } \cline { 5 - 5 } Parameter (UFC/100ml) & E1 & E2 & & Moyenne \\
\hline Total flora & 10100 & 20300 & 15200 & \\
Faecal califorms & 10690 & 12800 & 11745 & \\
Escherichia coli & 6930 & 8200 & 7565 & $2.10^{3}$ \\
Fecal streptococci & 6930 & 7380 & 7155 & $10^{3}$ \\
anaerobic sulphite reducers' spores & 1500 & 160 & 830 & \\
\hline
\end{tabular}

\section{DISCUSSION}

The average values of temperature and $\mathrm{pH}$ respectively equal to $30.3{ }^{\circ} \mathrm{C}$ and 6.7 , are perfectly in line with the Benin standards of liquid waste discharge which recommends a temperature of $30{ }^{\circ} \mathrm{C}$ (with a maximum deviation of $1{ }^{\circ} \mathrm{C}$ from that of the discharging area), and a pH between 6 and 9 for domestic waste water. The measured temperature values are slightly higher than those measured by Makoutodé et al. (2000) on CNHU-HKM effluents, and those measured by Aissi et al., (2013) in health zones of Abomey-Calavi and So-Ava. The $\mathrm{pH}$ values obtained is in accordance with the WHO standard (2006), (Table 3). The trend is generally the same when comparing the measured parameters with those of other countries effluents. Thus, the $\mathrm{pH}$ values measured by Sadek et al (2012) on Sidi Kacem Provincial Hospital effluents range from 7.06 to 7.59 , those measured by Bouzid et al (2013) on Mohamed V hospital of Meknes (Morocco) effluents vary from 7.39 to 8.83 . They are in good agreement with those (5 to 8.8) reported by Boillot, (2008) on effluents of seventeen hospitals in France.

The electrical conductivity is used to estimate the overall mineralization and to estimate the total soluble salts in water (Rodier et al., 2009). The obtained values remain below the inferior limit of $2000 \mu \mathrm{S} / \mathrm{cm}$ (WHO, 2012). The CHU-MEL effluents have a lower conductivity values compared with those of Calavi and Sô-Ava sanitary zones effluents.
Indeed the conductivity value of these effluents varies between $3700 \mu \mathrm{S} / \mathrm{cm}$ and $4260 \mu \mathrm{S} / \mathrm{cm}$ (Aissi et al., 2013). For effluents from 17 hospitals in France, Boillot, (2008) reported conductivity values ranging from 11.2 to 313 $\mu \mathrm{s} / \mathrm{cm}$. Water with a conductivity between 600 and $1000 \mu \mathrm{S} / \mathrm{cm}$ being considered as a water with a high mineralization (SPE, 1997, Rodier et al., 2009), CHU-MEL effluents are strongly mineralized wastewater.

The mean dissolved oxygen level of $1.96 \mathrm{mg} / \mathrm{L}$ obtained is lower than the guideline $(6 \mathrm{mg} / \mathrm{L})$ set by the "L'ordonnance sur le déversement des eaux usées" (ODE) and also than the critical level (4 mg/L) below which the life of aerobic microorganisms is threatened (Cornaz, 2004). This low oxygenation of water may be either due to a high consumption of dissolved oxygen by the aerobic bacteria for the degradation of the organic matter or to a low photosynthetic activity of the phytoplankton (Hamaidi et al., 2009). It gives the effluents an anoxic and therefore reducing and asphyxiating character. Thus, this area could favor nitrite and sulfates reduction respectively into nitrites and sulfurs. Such modification may be responsible for the unpleasant odors of effluents (Rodier et al., 2009). This state of the environment justifies the high content of ammonia nitrogen (23.45 $\mathrm{mg} / \mathrm{L} \mathrm{NH}_{4}{ }^{+}$) compared with that of the oxidized forms of nitrogen $\left(0.6 \mathrm{mg} / \mathrm{L} \mathrm{NO}_{2}{ }^{-}\right.$ and $7.75 \mathrm{mg} / \mathrm{L} \mathrm{NO}_{3}{ }^{-}$). This fact could be explained 
by the oxidation of organic matters which in turn can give birth to ammoniacal nitrogen increasing (Gnagne et al., 2015).

As for Aissi et al. (2013) who obtained NTK values between 34.5 and $97.5 \mathrm{mg} / \mathrm{L}$, the NTK value obtained for CHU-MEL effluents, on average equal to $28.73 \mathrm{mg} / \mathrm{L}$, is higher than Benin standard which is $15 \mathrm{mg} / \mathrm{L}$. Total phosphorus decreases from the first sample to the second (13.02 to $0.37 \mathrm{mg} / \mathrm{L})$. The standard admitted in Benin is set a maximum of $2 \mathrm{mg} / \mathrm{L}$. The discharge of CHU-MEL effluents into the Cotonou lagoon could lead to eutrophication. Indeed, the excess of nutrients nitrogenous salts (ammoniac, nitrate, nitrite) and phosphorus salts (phosphates) that are required for aquatic life can cause eutrophication phenomenon in the area, particularly in closed or semi-closed zones (Gnagne et al., 2015) such as lagoon of Cotonou.

The concentration of suspended solids (SS) decreases from the first sampling to the second one, and drops from 398 to $47 \mathrm{mg} / \mathrm{L}$. The WHO standard for this parameter is 20 $\mathrm{mg} / \mathrm{L}$ and is lower than we obtained. These results corroborate the low level of dissolved oxygen in the sense that their degradation consumes a significant amount of available oxygen. The high concentrations of SS in the studied effluents added to that originated from other pollution sources (Adjahouinou et al., 2012) could prevent light penetration in water. As consequence, the photosynthesis process by phytoplankton under water will decrease because of the limited dissolved oxygen in the aquatic area (Dongo et al. 2013). BOD $_{5}$ is a parameter that allows the assessment of biodegradable organic materials fraction. The results analysis show that $\mathrm{BOD}_{5}$ concentrations are really high ( 53 and $38 \mathrm{mg} / \mathrm{L}$ ) instead of 25 $\mathrm{mg} / \mathrm{L}$ as recommended by the standard of domestic releases in Benin (Table 4).

According to the WHO standard, COD for effluents must be at least $90 \mathrm{mg} / \mathrm{L}$. In CHUMEL effluents, we recorded an average COD of $185.5 \mathrm{mg} / \mathrm{L}$ of $\mathrm{O}_{2}$ compared with $125 \mathrm{mg} / \mathrm{L}$ of $\mathrm{O}_{2}$ for the norm accepted in Benin. The $\mathrm{COD} / \mathrm{BOD}_{5}$ ratio (3.86) is greater than 2 showing that the CHU-MEL effluents are only moderately biodegradable (Rodier et al., 2009).
The quantities of lead and chromium found in these effluents are less than the Benin standard for industrial wastes set at $1 \mathrm{mg} / \mathrm{L}$ for lead and $0,1 \mathrm{mg} / \mathrm{L}$ for hexavalent chromium. Giving that the recovered quantity of heavy metal are less than the fixed norms, the heavy metal pollution of the CHU-MEL effluents is then relatively low.

Total coliforms are present in effluents with an average of $11.745 .10^{5} \mathrm{CFU} / 100 \mathrm{~mL}$. The results obtained are consistent with those of the preliminary studies, which revealed much lower levels of concentration than urban classical effluents (average $10^{4}$ and $10^{6}$ $\mathrm{CFU} / \mathrm{mL}$ ). Indeed, the literature classifies hospital effluents as being less burdened with coliforms than urban wastewater, having a coliforms concentration of $10^{10} \mathrm{CFU} / 100 \mathrm{~mL}$ (Boillot, 2008). The likely presence of antibiotic residus and of specific substances in effluents (disinfectants, antiseptic etc.) could explain this observation (Guessennd et al., 2013). These effluents contain a high concentration of $\mathrm{E}$. coli with an average value of 7,155,105 CFU/100 mL. The high density of E. coli bacteria in the waters analyzed clearly indicates their contamination by faecal germs (CEAEQ, 2000; Edberg et al., 2000). This state of facts therefore increases the epidemiological potential risk posed by their rejection without treatment (Servais et al., 2006).

The average number of streptococcal colonies per $100 \mathrm{ml}$ of effluent is $8.3 \times 10^{4}$ $\mathrm{CFU} / 100 \mathrm{~mL}$. The presence of streptococci and anaerobic sulphite reducers' spores shows that the contamination is recent (Clausen et al., 1977). The anaerobic sulphite reducers' spores are present in the effluents in an average of 4.75.10 $\mathrm{CFU} / 100 \mathrm{~mL}$. Indicating the effectiveness of the treatments, their presence shows a failure of the filtration (Rodier et al, 2009).

Most physicochemical and microbiological parameters exceed the norms admitted. This shows that those effluents present enormous risks for the living organisms of the lagoon. We proposed, based on all the above-mentioned results, that CHU-MEL effluent treatment system be reinforced and monitored. 


\section{Conclusion}

This study was carried out to characterize the CHU-MEL effluents that are discharged into the Cotonou lagoon. The results show that effluents from CHU-MEL are in a state of undesirable pollution. In fact, the concentration of the various physicochemical and microbiological parameters analyzed exceeds the standards admitted for either industrial or domestic liquid waste.

Direct discharge of effluents without adequate treatments can have negative impacts on the trophic status of the lagoon's water and on the life of living organisms in this ecosystem. As with other sources of pollution, CHU-MEL effluents could play a capital role in the deterioration of the physicochemical and microbiological quality of the waters of the lagoon. Therefore, it would be benefic to assess the risk posed by the direct discharge of CHUMEL effluents into the Cotonou lagoon.

\section{COMPETING INTERESTS}

Authors have declared that no competing interests exist.

\section{AUTHORS' CONTRIBUTIONS}

EASA: main author of the work; BB: Contribution in field work; CDA: Contribution in field work, advisory support and rereading of the manuscript; WGK: Advice, proofreading and translation of the manuscript in English; LK: Support and review of the manuscript; BCC: Support and review of the manuscript; EDF: Director of the Laboratory of Research on Wetlands (LRZH): Direction and supervision of a hydrobiological part of the work; PAE: Director of the Laboratory of Research in Biochemistry and Toxicology of the Environment (LaRBiTE): Supervisor of toxicological and ecotoxicological parts of the work, Thesis supervisor.

\section{REFERENCES}

Adam KS, Boko M. 1993. Le Bénin (collection $\mathrm{n}^{\circ} 26,5 \mathrm{eme}$ edn). Edicef: France.
Adjahouinou DC, Liady ND, Fiogbe ED. 2012. Diversité phytoplanctonique et niveau de pollution des eaux du collecteur de Dantokpa (Cotonou-Bénin). Int. J. Biol. Chem. Sci., 6(5): 1938-1949. DOI: http://dx.doi.org/10.4314/ijbcs.v6i5.4

Aissi AK, Edorh PA, Degbey C, Guedenon P, Segbo J, Hounkpatin ASY, Boko M, Loko F. 2013. Assessment of risk connected to the management of effluents from Abomey-Calavi and So-Ava Laboratories. British Journal of Applied Science \& Technology., 3(2): 307-319. DOI:

http://dx.doi.org/10.9734/BJAST/2014/2 296

Boillot C. 2008. Évaluation des risques écotoxicologiques liés aux rejets d'effluents hospitaliers dans les milieux aquatiques : Contribution à l'amélioration de la phase «caractérisation des effets ». Thèse de doctorat, Institut National des Sciences Appliquées de Lyon, Lyon, France, p. 292.

Bouzid J, Chahlaoui A, Zaid A, My Mehdi R, Bouhlou L. 2013. Étude bactériologique et physico-chimique des effluents liquides de l'hôpital Mohamed V de Meknès (Maroc). ScienceLib., 5(130803): 1-15.

CEAEQ (Centre d'Expertise en Analyse Environnementale, Gouvernement du Québec). 2000. Recherche et dénombrement des coliformes fécaux; méthode par filtration sur membrane. Québec, p. 24.

Clausen EM, Green BL, Litsky W. 1977. Fecal streptococci: indicators of pollution. Dans: Hoadley, AW et BJ Dutka, édt., Bacterial indicators/Health hazards associated with water. American Society for Testing and Materials, ASTM STP., 635: 247-264.

Cornaz S. 2004. Evaluation du statut trophique d'un canal de drainage sous l'impact des pollutions d'origines diffuses et ponctuelles, le cas du grand canal de 
plaine de Rhône. Institut de Géographie de l'Université de Lausanne, Lausanne, p.180.

Dongo KR, Niamke BF, Adje AF, Britton BGH, Nama LA, Anoh KP, Adima AA, Atta K. 2013. Impacts des effluents liquides industriels sur l'environnement urbain d'Abidjan - Côte D'Ivoire. Int. J. Biol. Chem. Sci., 7(1): 404-420. DOI : http://dx.doi.org/10.4314/ijbcs.v7i1.36

DHSA (Direction des Hôpitaux et des Soins Ambulatoires). 2004. Guide de gestion des déchets des établissements de soins. Ministères de la santé du Royaume du Maroc, Maroc, p. 57.

Edberg SC, Rice EW, Karlin RJ, Allen MJ. 2000. Escherichia coli: the best biological drinking water indicator for public health protection. Journal of Applied Microbiology., 88: 106S-116S.

Emmanuel E. 2004. Évaluation des risques sanitaires et écotoxicologiques liés aux effluents hospitaliers. Thèse de doctorat, Spécialité Sciences et Techniques du Déchet, Institut National des Sciences Appliquées de Lyon, France, p.259.

Emmanuel E, Hanna K, Bazin C, Keck G, Clement B, Perrodin Y. 2005. Fate of glutaraldehyde in hospital wastewater and combined effects of glutaraldehyde and surfactants on aquatic organisms. Revue:Environ. Int., 31(3): 399-406.

Gnagne YA, Yapo BO, Meite L, Kouame VK, Gadji AA, Mambo V, Houenou P. 2015. Caractérisation physico-chimique et bactériologique des eaux usées brutes du réseau d'égout de la ville d'Abidjan. Int. J. Biol. Chem. Sci., 9(2): 1082-1093. DOI:

http://dx.doi.org/10.4314/ijbcs.v9i2.44

Guessennd NK, Ouattara MB, Ouattara ND, Nevry RK, Gbonon V, Tiekoura KB, Dosso M, le GER BMR. 2013. Étude des bactéries multirésistantes des effluents hospitaliers d'un centre hospitalier et universitaire (CHU) de la ville d'Abidjan (Côte d'Ivoire). J. Appl. Biosci., 69:5456 -5464 .

Hamaidi MS, Hamaidi F, Zoubiri A,
Benouaklil F, Dhan Y. 2009. Etude de ladynamique des populations phytoplanctoniques et résultats préliminaires sur les blooms toxiques a cyanobacteries dans le barrage de Ghrib (Ain Defla-Algérie). European Journal of Scientific Research, 32(3): 369-380.

Hartemann P, Hautemaniere A, Joyeux M. 2005. La problématique des effluents hospitaliers. Hygiène., 13(5) : 369-374.

Hisseien A, Kamga R, Mahamat TN. 2015. Physico-chemical analysis of Logone River water at Moundou City in Southern Chad. Int. J. Biol. Chem. Sci., 9(3): 16541664. http://ajol.info/index.php/ijbcs

Leprat P, Maftah C, Dagot C. 2002. Genotoxic activity of hospital wastewater: Behaviour of antineoplastic drugs in WWTP. In: New life for waste. Mons - Belgique. Province de Hainault, InNISMa, RECYWALL, FPMs., 122-126.

Makoutodé M, Touré O, Yarou A, d'Almeida AM. 2000. Traitement des déchets liquides au Centre National Hospitalier Universitaire de Cotonou au Bénin. Le Bénin Médical, 16:29-34.

OMS (Organisation mondiale de la santé). 1989. L'utilisation des eaux usées en agriculture et en aquaculture: recommandations à visées sanitaires. Rapport technique ${ }^{\circ} 778$. Genève.

OMS (Organisation mondiale de la santé). 2012. Directives OMS pour l'utilisation sans risque des eaux usées, des excréta et des eaux ménagères. OMS: Genève, 1-111.

OMS (Organisation mondiale de la santé). 2016. L'eau, l'assainissement et l'hygiène dans les établissements de soins de santé : état des lieux et perspectives dans les pays à revenu faible ou intermédiaire. OMS: Genève; 1- 37.

Philippot M, Bazin C, Preynat-Boucher P, Giannoli JM, Perrodin Y. 2016. Caractérisation de l'écotoxicité des rejets liquides des laboratoires de biologie médicale. Rev. Sci. L8217eau J. Water Sci., 29: 303-314. DOI: http://dx.doi.org/10.7202/1038929ar

Qadouri A, Mouhir L, Belkadi MS. 2016. Application d'une méthode d'étude 
quantitative et qualitative des rejets liquides hospitaliers au niveau de la Région de Marrakech Tensift El Haouz, Maroc. European Scientific Journal, 12(32): $\quad 110-130 . \quad$ DOI : http://dx.doi.org/10.19044/esj.2016.v12n $32 \mathrm{p} 110$

République du Bénin. 2006. Décret N²006$087 \mathrm{du} 08$ mars 2006 portant politique nationale d'hygiène hospitalière en république du Bénin. Journal Officiel de la République du Bénin. 1 - 27.

République du Bénin. 2001. Décret n²001109 du 4 avril 2001 fixant les normes de qualité des eaux résiduaires en république du Bénin. Journal Officiel de la République du Bénin. 1 - 27.

Rodier J, Legube B, Merlet N, Brunet R. 2009. L'Analyse de l'Eau (9e édn). Dunod : Paris.

Sadek S, Elkharrim K, Khadmaoui A, Guissouss M, Benelharkati F, Elmarkhi M, Driss B. 2012. Caractérisation physico-chimique des eaux usées de l'hôpital provincial de Sidi Ka-cem (Maroc). ScienceLib., 4(120713): 1-8.

Servais P, Garcia-Armisen T, Lizin P, Mercier P, Anzil A. 2006. Modélisation de la dynamique des indicateurs de qualité microbiologique en estuaire de Seine. Rapport scientifique Seine-Aval, 3 : 1-11.

SFHH (Société Française d'Hygiène Hospitalière). 1993. Bilan et recommandations sur les conditions de rejets des effluents liquides des établissements de santé - Rapport aux Ministères de la santé et de l'environnement. Paris, 1 - 32.

WHO (World Health Organization). 2006. Guidelines for the safe use of wastewater, excreta and greywater. Geneva, $1-36$.

Zounkovà R, Hilscherovà K, Blàha L, Houloubek I. 2006. Evaluation of ecotoxicity and genotoxixity of special (hospital) wastewaters (Poster). In SETAC Europe, 5(6) : 7-11. 